\title{
History of Grape in Anatolia and Historical Sustainable Grape Production in Erzincan Agroecological Conditions in Turkey
}

\author{
Muhammed Yasin Taskesenlioglu ${ }^{1}$, Sezai Ercisli ${ }^{2, *} \mathbb{C}$, Muhammed Kupe $^{2}{ }^{-}$and Nazan Ercisli ${ }^{3}$ \\ 1 Department of History, Faculty of Letters, Atatürk University, Erzurum 25240, Turkey; \\ ytaskesen@atauni.edu.tr \\ 2 Department of Horticulture, Faculty of Agriculture, Atatürk University, Erzurum 25240, Turkey; \\ muhammed.kupe@atauni.edu.tr \\ 3 Department of English Language and Literature, Faculty of Letters, Atatürk University, Erzurum 25240, \\ Turkey; nercisli72@gmail.com \\ * Correspondence: sercisli@atauni.edu.tr; Tel.: +90-535-639-56-07
}

Citation: Taskesenlioglu, M.Y.; Ercisli, S.; Kupe, M.; Ercisli, N. History of Grape in Anatolia and Historical Sustainable Grape Production in Erzincan Agroecological Conditions in Turkey. Sustainability 2022, 14, 1496 https://doi.org/10.3390/su14031496

Academic Editor: Emanuele

Radicetti

Received: 6 January 2022

Accepted: 26 January 2022

Published: 27 January 2022

Publisher's Note: MDPI stays neutral with regard to jurisdictional claims in published maps and institutional affiliations.

Copyright: (C) 2022 by the authors. Licensee MDPI, Basel, Switzerland. This article is an open access article distributed under the terms and conditions of the Creative Commons Attribution (CC BY) license (https:// creativecommons.org/licenses/by/ $4.0 /)$.

\begin{abstract}
The Anatolian peninsula has long been linked with the origins of viticulture and winemaking. Erzincan province in Anatolia hosted many civilizations in the past, and each civilization used grapes for different purposes. From past to present, viticulture carried out with the famous 'Karaerik' grape (Vitis vinifera L.) on old traditional Baran training system to avoid cold damage occurred in winter months. During the old civilizations, the cultivar was used only for wine production, but after the first period of the 1900s, this situation changed, and the cultivar was used for table consumption because wine is banned by Islam. The archaeological findings in Erzincan province revealed the cultivar has existed in the province for centuries, and in each historical period, the cultivar was used sustainably, added value to the region, and brought cultural heritage from generation to generation. Grape production in Erzincan province has been a symbol of abundance, fertility and productivity since mythological times. The historical facts indicated that viticulture and winemaking had been a dispensable part of the Erzincan economy and rural development. The vineyards apply the same sustainable management practices from which they receive their grapes. The traditional Baran training system is used for all vineyards. The viticulture in the province has been strongly committed to improving environmental and social sustainability throughout history.
\end{abstract}

Keywords: history of grape; Anatolia; sustainable grape production; Erzincan agroecological conditions; Turkey

\section{History of Sustainable Viticulture in Anatolia and Erzincan Province}

Grapes, olives, pomegranates and figs are the oldest fruits that have existed since prehistoric times and have survived to the present day. The grapevine (Vitis vinifera L.), apart from being one of the most extensively cultivated fruit trees in the world, is also a fascinating subject for history and evolutionary studies [1,2].

The grape has been the source of not only nutrition but also beliefs and symbols in people's daily lives throughout history $[3,4]$. Grapes are fruits cultivated all over the world, known from ancient times, also used as a therapeutic, food and drink (wine) $[5,6]$ compound obtained from grapes that are full of antioxidants (i.e., resveratrol), with published data revealing that the structure of the chemical substances extracted from grape fruits are strongly related to their antioxidant properties [7-9].

The concentrations of the antioxidant compound in plants are known to be affected by a range of physiological and environmental factors, including ripeness of the fruit, variety choice, pedo-climatic conditions, agronomic practices, disease and pest damage, fruit maturity, and length of post-harvest storage [10-12].

In most of the ancient growing areas in the world, there is a growing interest in using interesting local grape varieties to use them in sustainable grape production [13-17]. 
Sustainable agriculture has developed from three perspectives: as a system of production to achieve food self-reliance; as a concept of stewardship; and as a vehicle for sustaining rural communities. The concept of sustainability is not new to the farming practice, agricultural science, nor even to agricultural policy. In fact, throughout history, sustainable agriculture has been defined as simply agriculture that can continue indefinitely without depleting the resource base upon which it depends [18-20].

Sustainable viticulture corresponds to a global strategy in the scale of production and processing systems for grapes, which combines both the economic sustainability of structures and territories with the achievement of quality products, considering the demands of precision viticulture, the risks related to the environment, the safety of the product and the health of consumers and also the enhancement of heritage, historical, cultural, ecological and landscape aspects [21-23].

The extensive agricultural practices commonly used in the production of grapes in Anatolia, including Erzincan province, do not seriously deplete the resource base upon which it depends (Figure 1).

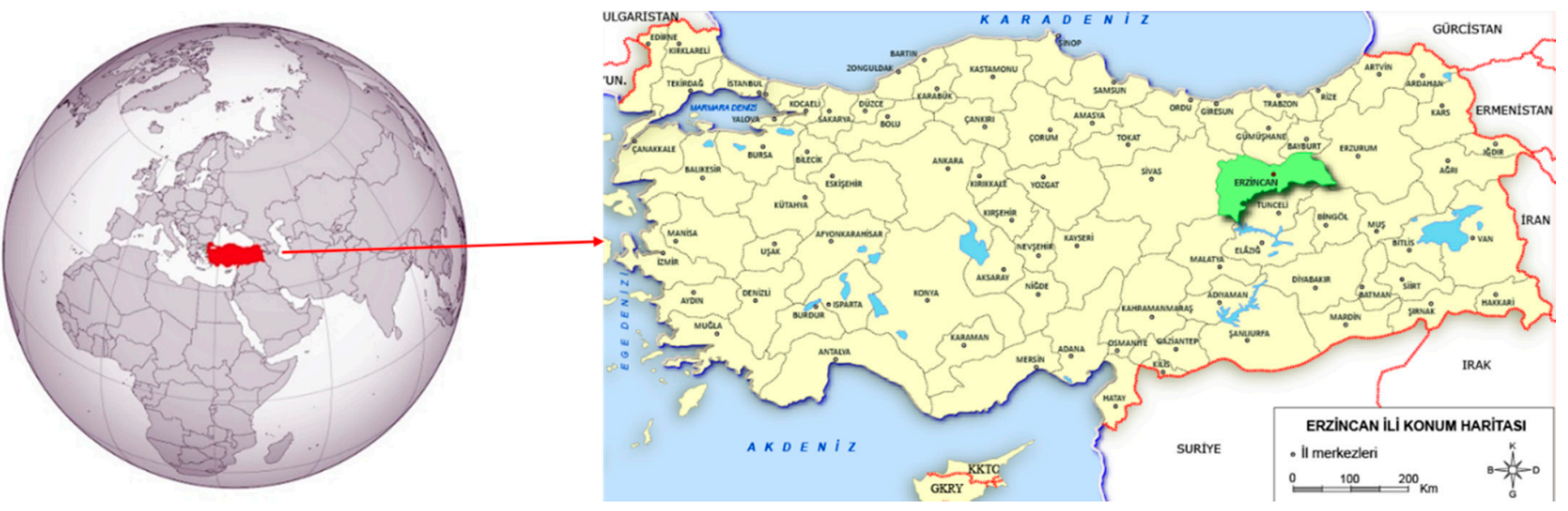

Figure 1. Map of Turkey and Erzincan province.

Using sustainable soil management practices was common in grape-growing regions around Anatolia in response to an increased awareness of the value of soil health to maintain environmental quality, crop yield, and grape quality throughout history. Thus, for centuries, in Anatolia, agricultural practices did not increase soil salinity, reduce the quantity and quality of irrigation water, thus accepted as sustainable. Throughout Anatolian history, it is accepted that sustainable agriculture practices enhanced the quality of life for farmers and society as a whole [24-26]. In Anatolia and Erzincan, most of the vineyards are not planted on hillsides. Thus, there is little soil erosion in the vineyard in these areas. Moreover, throughout history, extensive use of irrigation was not evident. Thus, groundwater levels have not been dropping rapidly in Anatolia.

Viticulture is one of Erzincan's most recognizable and valuable national assets. The history of viticulture in Erzincan dates back thousands of years. Because of sandy soil characteristics, there were no soil-plant pest (e.g., phylloxera) issues in the province and reveal great advantage for sustainable grape production in the province throughout history. Grapevines in Erzincan are considered immune from leaf phylloxera because their climatic conditions were not suitable for the biological cycle of the insect $[27,28]$.

About $99 \%$ of this area is planted with the indigenous grape 'Karaerik' (black). The grape production method has remained essentially unchanged since $800 \mathrm{BC}$. 'Karaerik', as an indigenous, is well adapted to the soil and climatic conditions of Erzincan. In comparison to introduced varieties, it requires fewer inputs (e.g., pesticides, fertilizers) for grape production $[29,30]$.

Typically, most of the 'Karaerik' vineyards are non-irrigated and manure applied for centuries for nutrition that prevents soil salinity. Vineyards did use very low quantities 
of synthetic fertilizers, but no synthetic pesticides, representing they produce grapes sustainable way [30]. Previous studies showed that sustainable procedures applied to viticulture must obviously be taken into account during production [31-33]. These are the quality and type of fertilizers [34], climate change [35], the quality and properties of the soil [36], rootstocks [37], and the type of grapes grown [38]. The published studies above clearly revealed all the factors influencing vines cultivation.

The aim of the study is to search the history of grapes in Anatolia and Erzincan province. To our knowledge, no detailed investigation about the history of grapes in Anatolia and Erzincan province has not been reported to date.

\section{History of Viticulture in Anatolia}

Viticulture has been carried out in a very wide area in the world. There are very different opinions about the origin center of the grapevine dating back millions of years; however, due to its great richness in form, Caucasia, the south of the Caspian Sea, and north-east Anatolia regions are shown as its origin center. Geological and archaeological research revealed that grapevine was grown in many parts of the world, even 60 million years ago. It shows that it is as old as the history of humanity and that the culture of viticulture started in Anatolia during those years [39,40].

History demonstrates that grapes and wines have been an important part of all civilizations in all areas of human life in Anatolia. Throughout history, the grape has been played a vital role in people's beliefs, and they used grape symbols in their religious and daily life as well as on the architectural works in their living spaces. This is a sign of the importance they give to grapes. The biggest proof of this is the archaeological excavations from the mythological era to the present [41-46].

These symbols are seen in historical artefacts. Since then, the grape has continued to be one of the most important crops in Anatolia civilizations. In the mythological period, grapes and grape by-products were dedicated to the Gods, and grapes were always included in artistic works in Anatolia [47,48].

Grapes and wine have maintained their importance in every period of history in Anatolia. In monotheistic religions, wine, which gained a religious meaning, especially in the Christian period, has a great value. With the spread of Islam, the importance of wine in Muslim-dominated places has decreased or been lost. However, grapes and grape figures continued to take their place in art $[49,50]$.

For most of the Anatolian civilizations, wine was associated with immortality, wisdom, truth and love in history and its God (Dionysus: god of wine and vintage) in Greek mythology [51].

Grapes were a popular agricultural product in ancient civilizations. The main reason for their popularity was undoubtedly the wine produced. It is therefore easy to see why the god of wine and viticulture, Dionysus, appeared in Ancient Greece. A renowned historical geography scholar, Dan Stanislawski [52], likewise explains the reason for the appeal of the Dionysian cults; "the century that was, not coincidentally, the period of earliest important Greek colonization, a movement largely based on commercial agriculture. From that century onward, Dionysian cults and wine were symbiotic". The importance of wine and agriculture to ancient Greeks affected their lives with the creation of the Dionysian cults as a religion. Greeks worshipped Dionysus for giving them the gifts of wine and freedom. Celebrating the god's gift to mortals at festivals was a ritual, and drama emerged out of the ritual itself. Therefore, it is accepted that drama emerged as a kind of worship [53]. At the core of the festivals for Dionysus, starting with spring, were the pleas to the god of wine for a fruitful harvest of the grapes and all products. These supplications to the god of fertility and wine reflected the desire for nature to be reborn with spring and for the fertility of the soil, which would die with the coming of winter. Dancing around an altar and drinking wine were prototypes of modernist dramaturgy in the fourth century BC. Aristotle defined the principles of drama as based on the imitation of action. Wine and grapes contributed to drama emerging as the favourite form of art in Ancient Greece and subsequently. The 
close relationship between drama and wine production and, therefore, grapes contributed to the continuity of each other in the inseparable unity of the cultures of entertainment and harvest.

It is not known exactly who discovered the wine, but archaeological findings point to Transcaucasia as the place where the grape was first domesticated. Anatolian lands attract attention with their proximity to this region, where wine and viticulture are born [39].

Anatolia is in the most suitable climatic zone of the world for viticulture apart from being the gene center of the grapevine, and it also has an extremely old and deep-rooted viticulture culture. The history of viticulture in Anatolia is quite old. From the archaeological excavations, the viticulture in Anatolia dates back to BC. It has been determined that it dates back to the years of $3500 \mathrm{BC}$ [51].

The fact that grapes, wine containers and amphora are included on the coins minted in the regions where viticulture is developed in the Aegean and Marmara regions (Lapseki, Çanakkale, Bergama, Aliağa and Dikili, Bozcaada, Çeşme, Karaburun and Seferihisar) within Anatolia shows the importance given to viticulture and wine. The history of Anatolian civilizations, vineyards and wines has always played an important role in their livelihood and trade. Throughout history, the grapes were mostly consumed as fresh or dried. In addition, some special products such as molasses, delight, köfter, pestil and delight were also obtained from grape juice, and this historical tradition occurred in all Anatolian civilizations and passed from one generation to generation as cultural heritage, and this old culture continues today as well in Anatolia [51,54].

The presence of figures and reliefs related to grapes in historical artefacts unearthed from archaeological excavations in different regions of Anatolia are the most important indicators pointing to the widespread viticulture culture in that region. Indeed, in excavations carried out in every part of Anatolia, important artefacts from prehistoric times related to viticulture have been found [55,56].

During the excavations, many findings related to wine culture in Anatolian civilizations were found. The name given to the leading cities in winemaking in the Hittites is 'wiyanawanda', the root of the word 'vin', which means wine, and 'wine'. In addition, the fact that the god of wine, Dionysus, lived in Denizli, Çal, gives us a very solid clue about the relation of these lands with wine [57].

The oldest wild grape seed remains in Turkey were found in different geographies of Anatolia. The remains of wild grapes found in Nevali Çori mound near Urfa trace back to 8400 years ago [47]. The remains in the Canhasan mound, which are within the borders of Karaman province today, date back to the Chalcolithic Age [49]. According to the same source, the cultivated grapes encountered in the Altinova settlements of Elazig (Korucutepe, Tepecik, Tülintepe) towards the end of 3 BC [49]. In addition, recent studies show that grapes have a much older history in Anatolia. According to the results of the Diyarbakır Körtik Tepe excavations, the presence of tartaric acid, which is in the essence of the grape berries, was determined by the carbon test performed on the container found in the neo-lithic layer (Figure 2). This information has shown that grapes existed about 9000 years ago [58,59]. 


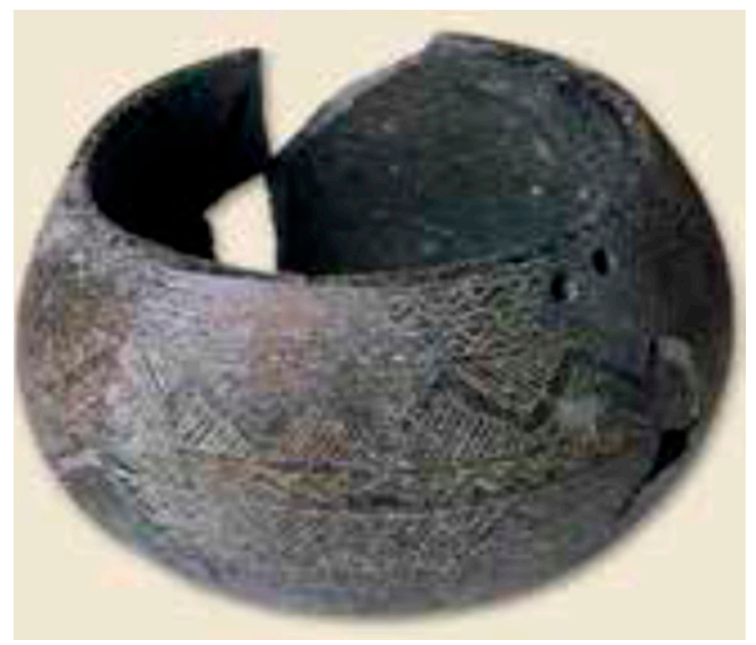

Figure 2. Container found in Diyarbakır Körtik tepe [59].

The importance of vine and grape has found their place in many historical ruins in Anatolian culture. Diyarbakir Ulu Mosque, which is the oldest mosque in Anatolia, was created by the conversion of Martoma Church into a mosque in 639 by Muslim Arabs. Vine leaves and bunches of grapes (Figure 3) used in the decoration of the mosque are remarkable [60].

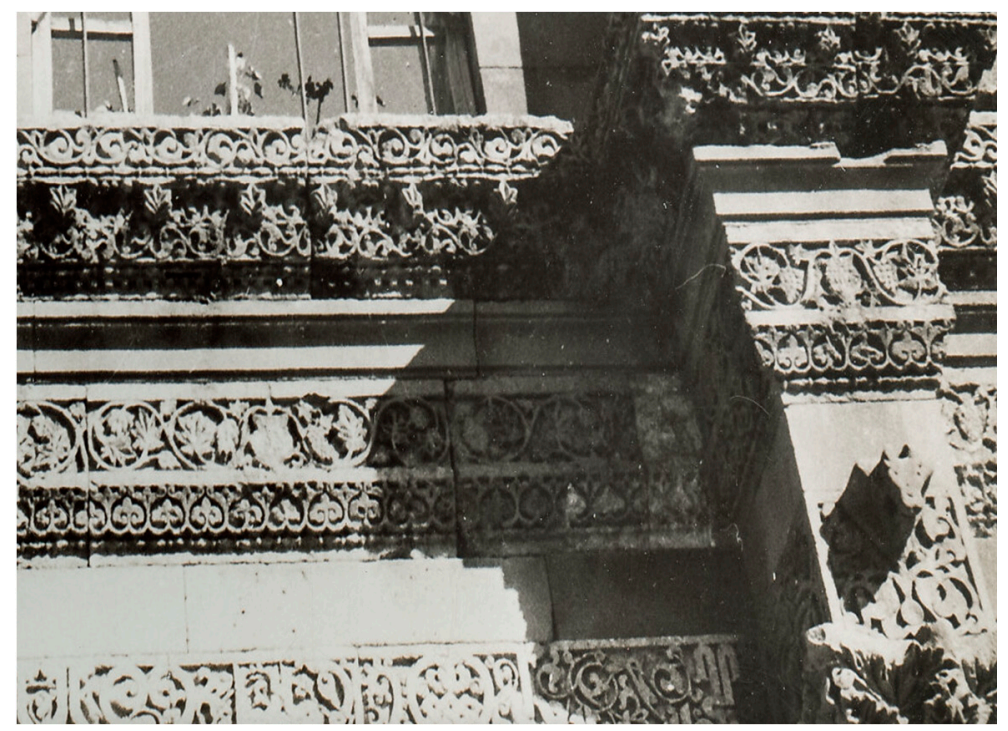

Figure 3. Grape leaves and bunches on wall of Diyarbakır Ulu Mosque [60].

Hanging Gardens of Babylon, one of the seven wonders of the world, is located on the banks of the Euphrates in Anatolia. Three structures unearthed in archaeological excavations have turned the eyes of the world to Babylon: the ruins of the Hanging Gardens, the Tower of Babel and a magnificent street. The ancient inscriptions and clay tablets found in the excavations revealed the hanging gardens of Babylon, which is called the hanging gardens of Queen Semiramis, in ancient sources [61,62].

Vine and grape figures were also frequently used on fountain heads and tombstones during different civilizations in Anatolia. In addition, the hanging figure has become one of the indispensable patterns of stonework in exterior decorations [63]. Viticulture in Anatolia was performed in many regions, e.g., the Menua (Semiramis, Samram) irrigation canal and the hanging gardens around it, which remained from the Urartians (900-600 BC) in Van, are widely described in old documents sources [60]. 


\subsection{Viticulture in Hittites Perio}

The history of viticulture is intertwined with Anatolian civilizations. Many archaeological findings from the Hittites, who came to Anatolia in $2000 \mathrm{BC}$ and created a great civilization of 600 years, have survived to the present day, explaining the importance of viticulture. In addition, the presence of figures of grapes and wine in the rock paintings and sculptures of this period, the special provisions regarding the protection of the vineyards, and the product of the Hittite laws. The mention of raisins in the Boğazköy texts are the other documents that bring the importance of Anatolian viticulture to the present day. From the archaeological findings, grapevine and wine were of great importance in the Hittites period in Anatolia. It is recorded that viticulture was very well developed in the years of 1800-1550 BC, and grapes and wine were offered as offerings to the gods in religious ceremonies and social life [46].

The Hittites also applied agricultural laws under today's understanding to protect their assets, such as vineyards and gardens. From the excavations obtained in Yozgat Alişar, wine and drinking bowls in the form of bunches of grapes dating back to 1800-1600 BC were found. In addition to all these, in Çorum Alacahöyük, one of the king's tombs, the discovery of a golden wine glass and a wine jug date back to $2300 \mathrm{BC}$ [48].

On the other hand, the ruins in Central Anatolia, which belonged to the Hittites, who had one of the most exceptional places in Anatolian history, shed light on the history of grapes in Anatolia. Grape remains dated to 2 and 1 BC were identified in the results of the research bearing archaeobotanical identity [64]. In wine production, the Hittites concentrated on places with years of experience in grape growing. It was identified as the oldest wine container in Anatolia and dated back to 3000 BC. The wine jug (Figure 4), which is thought to belong to the year $3000 \mathrm{BC}$, has proved this [50].

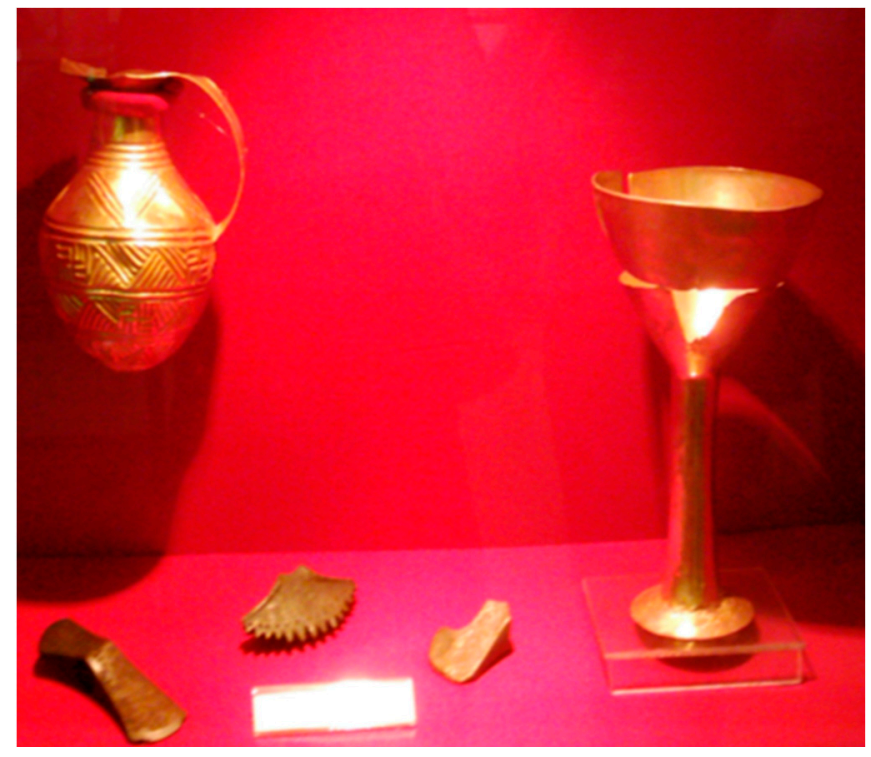

Figure 4. Grape findings in Hittite's era [48].

Although the Hittite civilization comes to mind first for the history of viticulture and winemaking in Anatolia, the Hittites learned about viticulture from the people who lived in Anatolia before. The Assyrians were very advanced in winemaking. Again, the Assyrians traded raisins and wine by transporting them from the place where they were produced. In the excavations made in Diyarbakir 1300 BC, the discovery of grape fossils and tools related to winemaking shows that the civilization of grapes goes back much further [60].

One of the most important pieces of evidence of the use of a product in the region is the findings obtained from the archaeological excavations. In particular, the remains of objects that are used or consumed intensively are indispensable from archaeological 
excavations. Anatolia is a geography where grapes have been consumed and cultivated for thousands of years.

During the excavations carried out in every region of Anatolia, important artefacts from prehistoric times related to viticulture were found. Grape seed fossils dating back to the fourth and fifth centuries have been found in the Çanakkale Hisarlık region, where people carried many grape clusters side by side. The lamp belonging to $1750 \mathrm{BC}$ was found in Konya Karahöyük [62].

The history of viticulture in Anatolia begins with the civilizations in Anatolia. The history of wine was born in the Hittite era, which was not suitable for use in much older days. A wine glass and concept of wine from the Hittite era 3000 BC exhibited in the Museum of Anatolian Civilizations is the oldest wine container [48].

\subsection{Grapes in Phrygian, Persian, Roman and Byzantine Civilization}

The Hittites, who migrated from Anatolia to Crete and Aegean islands and pioneered the establishment of the Minoan civilization (2200-1400 BC), had an enormous impact on the spread of viticulture culture in the west of Anatolia. Viticulture started in Crete by the Minoan civilization, then spread to the Peloponnese and Thrace. The Greeks, and especially the Phoenicians, who were the leading societies of maritime trade, carried the viticulture culture to the west of the Mediterranean [60].

After the Hittites, Anatolia continued to be home to various civilizations. Of these, viticulture maintained its importance during the Phrygian and Persian civilizations and throughout the Hellenistic period. In the Phrygian Region of Anatolia, gods were depicted on votive stelae during the Roman Period (200-300 AD). Zeus Ampelikos and Zeus Ampeleitos were believed to be these, and they were believed to protect the vineyards [60].

Grape figures draw attention to the mosaics on the floors of the churches, which are understood to belong to the Byzantine and Roman periods (4th-6th centuries AD) during the archaeological excavations in the ancient city of Hadrionoupolis (Karabük) Figures 5 and 6 [65].

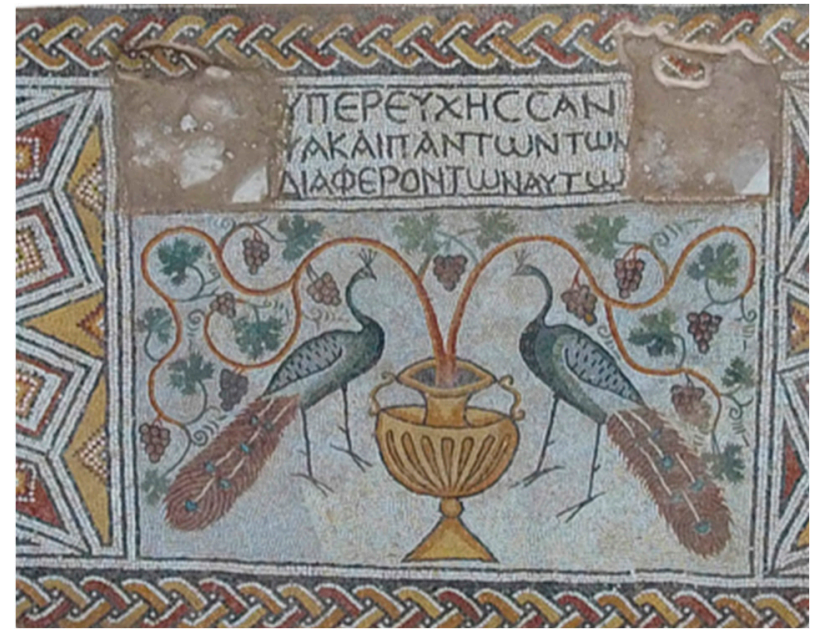

Figure 5. Grape figures in Hadrionopolis city [65]. 


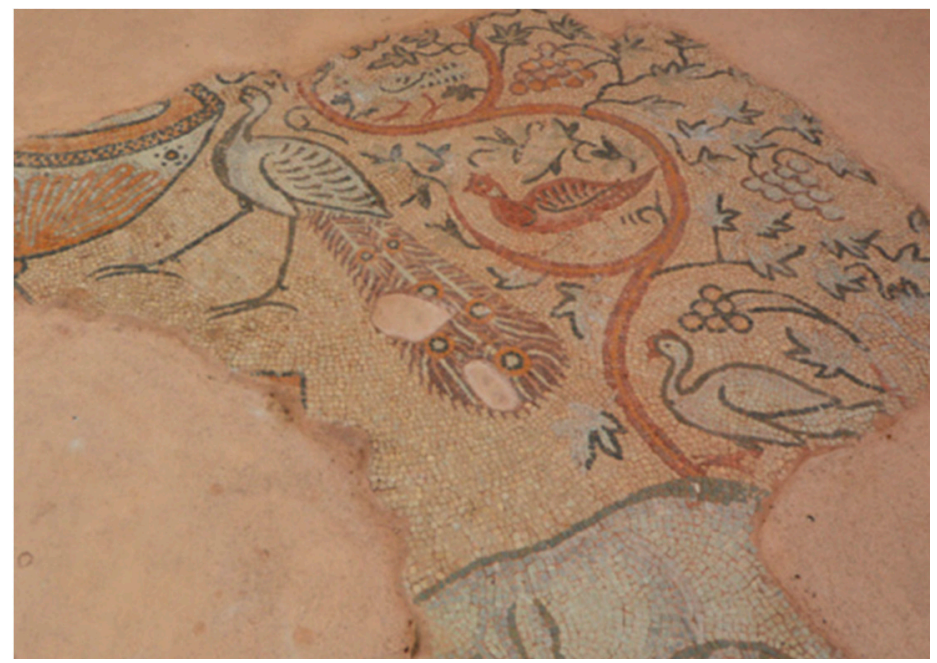

Figure 6. Grape figures in Hadrionopolis city [65].

Near Erzincan, the grape figures in the mosaics of the church in Altintepe, which date back to the 6th century, can be considered as the oldest records about Erzincan and even 'Karaerik' grape (Figure 7) [66].

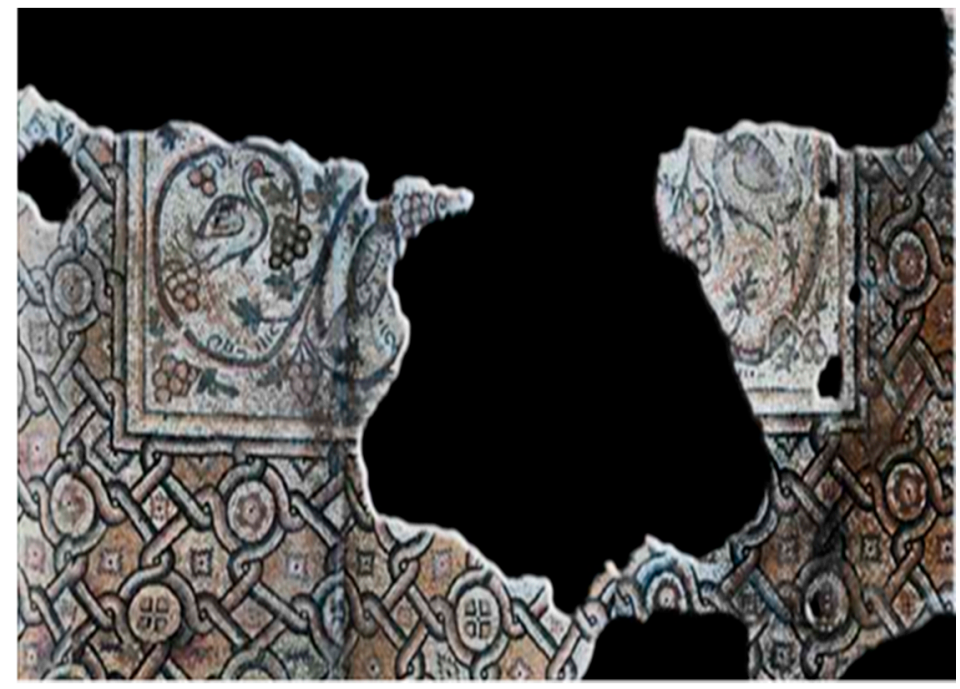

Figure 7. Grape figures on ground mosaics of Altıntepe church [66].

\subsection{Grapes in Seljuk and Ottoman Civilization}

It is seen that vine and grape were used in the wall tiles of mosques and palaces in the Seljuk and Ottoman Periods. This is the most important evidence that the value attached to the vine by the Muslim Seljuks and Ottomans continued in a similar way to other societies. Table grape cultivation, which is very different and new for Europe, spread from the Balkans to Italy, France and Spain during the Ottoman Empire. Vine leaves and bunches of grapes were significant figures in Seljuk and Ottoman decorations [47,50,54].

Grape growing and wine production, which has been going on since ancient times, continued in the Ottoman Empire as well, and even though winemaking was forbidden for the Muslim people, the tax of non-Muslims was levied, and the trade of grapes and wine was allowed [67]. During the Ottoman Empire, Erzincan was at the forefront of grape growing. As a matter of fact, it is known that the main fruit grown in Erzincan at the beginning of the 16th century was grapes. The grapes grown in the vineyards were used to make must and wine [68]. 
Evliya Çelebi's Travel Book contains important information about local grapes. Evliya Çelebi, who reached Erzincan on his eastern Anatolia trip in the 1640s, among the treats offered was grapes [69]. He mentioned that in the vineyard with its leaves on the clean soil with amber scent. They brought the buried grapes. In a printed copy of Evliya Çelebi's Travel Book, the grape remains until a new one comes [70]. This information shows that the grapes are kept under the ground with their leaves, making them suitable for consumption even out of season

\section{Viticulture in Erzincan Today}

Erzincan province is accepted as one of Turkey's fascinating plant biodiversity centers. The province has produced grapes for centuries, and in particular, Üzümlü, Bayırbağ and Pişkidağ districts are more suitable for grape production (Figure 8).
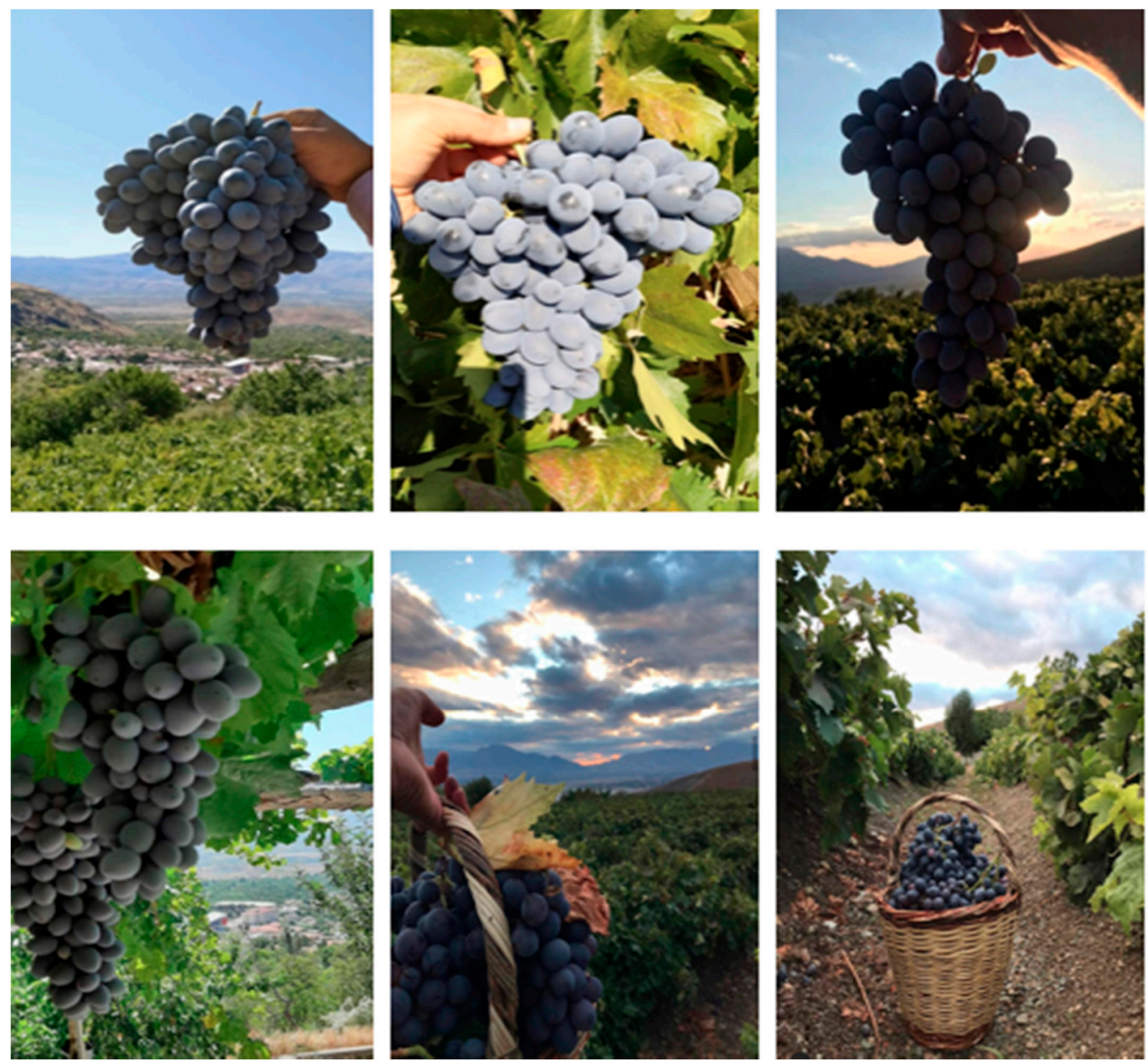

Figure 8. Sustainable 'Karaerik' grape production in Erzincan on Baran training system (Origina).

The province has microclimate conditions that allow the growth of several fruit species, including apricot, sweet and sour cherries, grapes, walnuts, mulberries, peaches, apples, pears, quinces, plums, almonds, etc. The province also has a great wild edible fruit potential, and the main wild edible fruits grown in the province for centuries are hawthorn, cornelian cherry, rosehip, cranberry bush, wild apricot, barberry etc.

Before the 1900s, the cultivar was used only for wine production, but after the 1900s, it was used only for table consumption. It is the first patented national grape cultivar in Turkey [25]. During the very long cultivation period, the cultivar was very much adopted in the Erzincan region. Viticulture practices have been conducted in the region in a sustainable way. The farmers use the traditional Baran training system, a unique system for the region (Figure 9). 


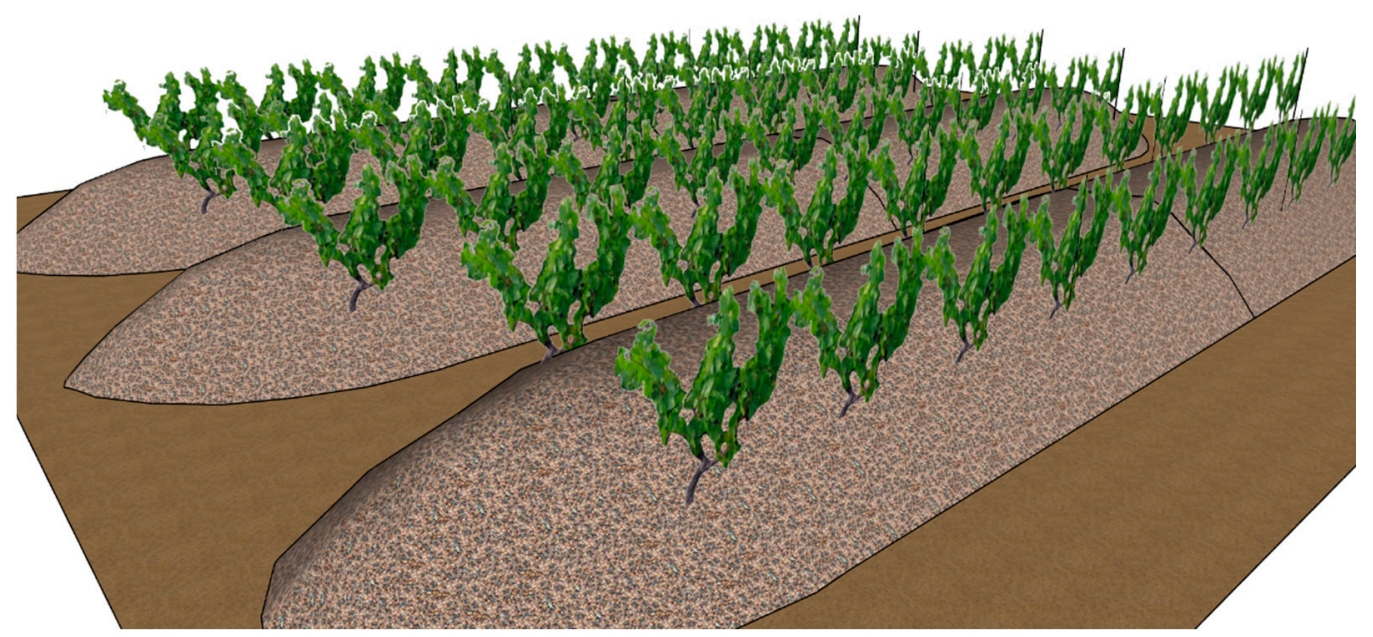

Figure 9. A schematic diagram of Baran training system.

The main reason to use the Baran system is to avoid cold winter damage. The traditional and sustainable Baran system is briefly covering the soil on the grapevine during the winter months to protective them from cold. In addition, the snow falling on the Baran system in winter plays a cold-protective role. One of the most important disadvantages of the Baran system is that the grape bunches come into contact with the soil and fungal infections appear. In order to prevent this, the use of mulch in vineyards has become widespread in recent years [71-73]. In this system, farmers, in general, care much about the environment and recognize the importance of healthy soil for successful grape production. They also used practices such as cover cropping and compost additions to obtain healthier grapes. 'Karaerik' grape is the symbol of the Üzümlü district. (Figure 10).
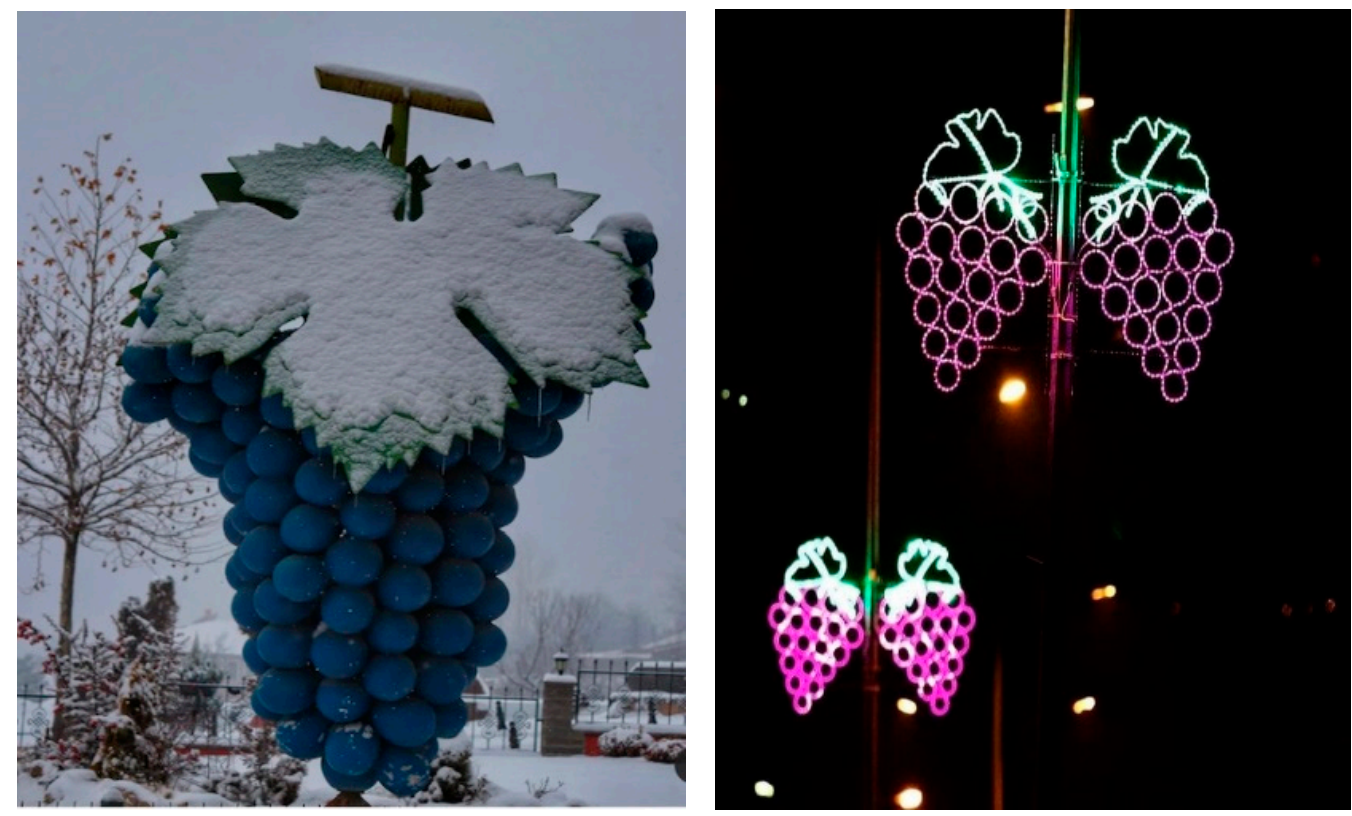

Figure 10. 'Karaerik' grape figure and lamps on streets in Üzümlü district.

\section{Important Compounds Extracted from Grape Fruits}

Grapes have been used fresh, dried, and as wine throughout history. From past to present, people have believed that grapes and grape products are very important for human health, and they have even traditionally used grapes and grape products as medicinal drugs in the treatments of different human diseases [40,50,51,74,75]. 
Grapevine (Vitis vinifera) products, grape and grape juice, represent a valuable source of bioactive phytochemicals and stored in different plant tissues. In the last decades, compelling evidence suggested that regular consumption of these products may contribute to reducing the incidence of chronic illnesses, such as cancer, cardiovascular diseases, ischemic stroke, neurodegenerative disorders and aging, in the context of the Mediterranean dietary tradition. The health benefits arising from grape product intake can be ascribed to the potpourri of biologically active chemicals occurring in grapes [14-16].

The nutritive value of grapes, which is one of the most produced fruits in the world, is very high. It contains plenty of sugar, mineral substances, vitamins and polyphenol groups. It is high in calories due to its high sugar content. It consists of minerals, mostly calcium, potassium, sodium and iron-grapes containing A, B1, B2, B3 and C vitamins. Grape contains tannin, proanthocyanidin, resveratrol and fruit acids such as tartaric, malic, succinic, citric, oxalic and caffeic acids as well [74-76].

Among the flavonoid compounds, which are among the polyphenol groups, the most common ones found in grapes are: flavonols quercetin, campferol, myricetin, flavan-3-ols, tannins and anthocyanins (Table 1). Anthocyanidins (malvidin, peonidin, petunidin, cyanidin, delphinidin) are flavonoids that give grapes and grape products their characteristic colors. The most common phenolic acids in grapes are hydroxycinnamic acid, gallic acid derivatives, and trans-resveratrol [77].

Grapes have a very high antioxidant capacity. Major antioxidant substances in grape fruits are beta carotene, Vitamins A, C and E, selenium, manganese, flavonoids and phenolic compounds. Grape fruit is rich in phenolic substances, stilbenes, flavonoids and anthocyanidins, and thus it is considered among the super fruits in terms of human health. Resveratrol, one of the stilbenes, is nowadays discovered as the best of the antioxidants. This substance especially has a positive effect on vascular occlusion, cardiovascular diseases, certain neoplasm diseases and the immune system. It has been found that it is useful for the problems related to health and prolongs the lifespan [78-80].

Table 1. Main compounds of grape fruits their action on human health.

\begin{tabular}{|c|c|c|c|c|}
\hline Class & Subclass & Compound & Main Findings & References \\
\hline \multirow[b]{2}{*}{ Flavonoids } & Flavanones & $\begin{array}{c}\text { Naringenin, } \\
\text { hesperetin, } \\
\text { eridicytol }\end{array}$ & $\begin{array}{l}\text { Improve microvascular endothelial reactivity; } \\
\text { Gradual reduction in diastolic BP; } \\
\text { Association with reduced progression of } \\
\text { atherosclerotic plaques; reduction in LDL-C, TG and } \\
\text { TC level; decreased MDA }\end{array}$ & [81-86] \\
\hline & Anthocyanidins & $\begin{array}{l}\text { Delphinidin, } \\
\text { Cyanidin, } \\
\text { Petunidin, } \\
\text { Peonidin, } \\
\text { Malvidin }\end{array}$ & $\begin{array}{c}\text { Reduction in central aortic stiffness and carotid } \\
\text { femoral pulse wave velocity; } \\
\text { Decreased oxidized LDL, serum 8-isoprostans levels, } \\
\text { monocyte chemotactic protein-1 (MCP-1) and high } \\
\text { sensitivity CRP (hsCRP) levels; } \\
\text { Decreased platelet aggregation; } \\
\text { Reduce both systolic BP and diastolic BP; inverse } \\
\text { relation between anthocyanin and CVD related risk } \\
\text { factors or fatality rate; } \\
\text { Reduced monocyte cell adhesion to human } \\
\text { endothelial cells by decreasing ICAM-1, VCAM-1 } \\
\text { and E-selectin along with proinflammatory } \\
\text { mediators M-CSF, IL-6 and MCP-1 in both monocyte } \\
\text { and endothelial cells; } \\
\text { Inhibited the production of NF- } \kappa \beta \text {, oxidative stress } \\
\text { and other inflammatory factors; } \\
\text { Increase FMD; }\end{array}$ & [87-93] \\
\hline Stilbenes & Resveratrol & & $\begin{array}{c}\text { Reduced the gene expression of IL-8, ETI, Sirtuin-1, } \\
\text { NFE2L2; and eNOS; } \\
\text { Less occurrence of CVDs or related complications; } \\
\text { Significantly increased total antioxidant status; } \\
\text { Reduced the levels of thrombogenic PAI-I and raised } \\
\text { the level of anti-inflammatory serum adiponectin; } \\
\text { Reduction in the LDL-C, ApoB, oxidized LDL and } \\
\text { oxidized LDL/ApoB while incrementing in } \\
\text { non-HDL-C/ApoB was observed }\end{array}$ & [94-100] \\
\hline
\end{tabular}




\section{Conclusions}

In conclusion, the Anatolia region is one of the most important diversity centers of viticulture, and the grape has been one of the most important elements of life in all civilizations that have lived in Anatolia before. Grape culture has been transferred from generation to generation in Anatolia and has survived to the present day, as in the example of Erzincan. Grape appears as the most important cultural heritage in today's Anatolia and is an element that reflects the lifestyles of different regions.

Author Contributions: Conceptualization, M.Y.T., M.K. and S.E.; data curation, M.Y.T., M.K., S.E. and N.E.; formal analysis, M.Y.T., M.K. and S.E. methodology, M.Y.T., N.E., M.K. and S.E.; project administration, M.Y.T. and S.E.; visualization, M.Y.T., N.E. and S.E.; writing-original draft, N.E., S.E. and M.Y.T.; writing-review and editing, N.E., S.E., M.Y.T. and M.K. All authors have read and agreed to the published version of the manuscript.

Funding: This study does not have funding.

Institutional Review Board Statement: Not applicable.

Informed Consent Statement: Not applicable.

Data Availability Statement: All-new research data were presented in this contribution.

Conflicts of Interest: The authors declare that they have no conflict of interest.

\section{References}

1. Ekhvaia, J.; Akhalkatsi, M. Morphological variation and relationships of Georgian populations of Vitis vinifera L. subsp. sylvestris (C.C. Gmel.) Hegi. Flora Morphol. Distrib. Funct. Ecol. Plants 2010, 205, 608-617. [CrossRef]

2. Naqinezhad, A.; Ramezani, E.; Djamali, M.; Schnitzler, A.; Arnold, C. Wild grapevine (Vitis vinifera subsp. sylvestris) in the Hyrcanian relict forests of northern Iran: An overview of current taxonomy, ecology and palaeorecords. J. For. Res. 2018, 29, 1757-1768. [CrossRef]

3. Marvelli, S.; De' Siena, S.; Rizzoli, E.; Marchesini, M. The origin of grapevine cultivation in Italy: The archaeobotanical evidence. Ann. Bot. 2013, 3, 155-163.

4. Zdunic, G.; Luksic, K.; Nagy, Z.A.; Mucalo, A.; Hancevic, K.; Radic, T.; Butorac, L.; Jahnke, G.G.; Kiss, E.; Ledesma-Krist, G.; et al. Genetic structure and relationships among wild and cultivated grapevines from Central Europe and part of the Western Balkan Peninsula. Genes 2020, 11, 962. [CrossRef]

5. Bouby, L.; Figueiral, I.; Bouchette, A.; Rovira, N.; Ivorra, S.; Lacombe, T.; Pastor, T.; Picq, S.; Marinval, P.; Terral, J.-F. Bioarchaeological insights into the process of domestication of grapevine (Vitis vinifera L.) during Roman times in Southern France. PLoS ONE 2013, 8, e63195. [CrossRef]

6. Bungău, S.G.; Popa, V.C. Between religion and science: Some aspects: Concerning illness and healing in antiquity. Transylv. Rev. 2015, 24, 3-19.

7. Capanoglu, E.; de Vos, R.C.; Hall, R.D.; Boyacioglu, D.; Beekwilder, J. Changes in polyphenol content during production of grape juice concentrate. Food Chem. 2013, 139, 521-526. [CrossRef]

8. Cosme, F.; Pinto, T.; Vilela, A. Phenolic compounds and antioxidant activity in grape juices: A chemical and sensory view. Beverages 2018, 4, 22. [CrossRef]

9. Glevitzky, I.; Dumitrel, G.A.; Glevitzky, M.; Pasca, B.; Otrisal, P.; Bungau, S.; Cioca, G.; Pantis, C.; Popa, M. Statistical analysis of the relationship between antioxidant activity and the structure of flavonoid compounds. Rev. Chim. 2019, 70, 3103-3107. [CrossRef]

10. Mulero, J.; Pardo, F.; Zafrilla, P. Antioxidant activity and phenolic composition of organic and conventional grapes and wines. J. Food Compost. Anal. 2010, 23, 569-574. [CrossRef]

11. Belitz, H.D.; Grosch, W.; Schieberle, P. Fruits and fruit products. In Food Chemistry; Springer: Heidelberg, Germany, 2004; pp. 806-861.

12. da Silva Haas, I.C.; Toaldo, I.M.; de Gois, J.S.; Borges, D.L.; de Oliveira Petkowicz, C.L.; Bordignon-Luiz, M.T. Phytochemicals, monosaccharides and elemental composition of the non-pomace constituent of organic and conventional grape juices (Vitis labrusca L.): Effect of drying on the bioactive content. Plant Foods Hum. Nutr. 2016, 71, 422-428. [CrossRef] [PubMed]

13. Biasi, R.; Brunori, E. The on-farm conservation of grapevine (Vitis vinifera L.) landraces assures the habitat diversity in the viticultural agro-ecosystem. Vitis 2015, 54, 265-269.

14. Hasanaliyeva, G.; Chatzidimitrou, E.; Wang, J.; Baranski, M.; Volakakis, N.; Pakos, P.; Seal, C.; Rosa, E.A.S.; Markellou, E.; Iversen P.O.; et al. Effect of organic and conventional production methods on fruit yield and nutritional quality parameters in three traditional cretan grape varieties: Results from a farm survey. Foods 2021, 10, 476. [CrossRef] [PubMed] 
15. Margraf, T.; Santos, É.N.T.; de Andrade, E.F.; van Ruth, S.M.; Granato, D. Effects of geographical origin, variety and farming system on the chemical markers and in vitro antioxidant capacity of Brazilian purple grape juices. Food Res. Int. 2016, 82, 145-155. [CrossRef]

16. Toaldo, I.M.; Cruz, F.A.; de Lima Alves, T.; de Gois, J.S.; Borges, D.L.; Cunha, H.P.; da Silva, E.L.; Bordignon-Luiz, M.T. Bioactive potential of Vitis labrusca L. grape juices from the Southern Region of Brazil: Phenolic and elemental composition and effect on lipid peroxidation in healthy subjects. Food Chem. 2015, 173, 527-535. [CrossRef]

17. Niu, S.; Hao, F.; Mo, H.; Jiang, J.; Wang, H.; Liu, C.; Fan, X.; Zhang, Y. Phenol profiles and antioxidant properties of white skinned grapes and their coloured genotypes during growth. Biotech. Biotechnol. Equip. 2017, 31, 58-67. [CrossRef]

18. Velten, S.; Leventon, J.; Jager, N.; Newig, J. What is sustainable agriculture? A systematic review. Sustainability 2015, 7, 7833. [CrossRef]

19. Deytieux, V.; Munier-Jolain, N.; Caneill, J. Assessing the sustainability of cropping systems in single- and multi-site studies. A review of methods. Eur. J. Agron. 2016, 72, 107-126. [CrossRef]

20. Siebrecht, N. Sustainable Agriculture and Its Implementation Gap-Overcoming Obstacles to Implementation. Sustainability 2020 12, 3853. [CrossRef]

21. Organisation Internationale de la Vigne et du Vin (OIV). Guidelines for Sustainable Vitiviniculture: Production, Processing and Packaging of Products; Organisation Internationale de la Vigne et du Vin: Paris, France, 2008; pp. 1-12.

22. Jones, G. Sustainable vineyard developments worldwide. Int. J. Enol. Vitic. 2012, 7, 7.

23. Oyaneder, L.; Valderrama, S. Sustainable balanced scorecard model for Chilean wineries. In Proceedings of the 8th International Conference of Academy of Wine Business Research, Geisenheim, Germany, 28-30 June 2014.

24. Fairbairn, A. A History of Agricultural Production at Neolithic Çatalhöyük East, Turkey. World Archaeol. 2005, 37, 197-210. [CrossRef]

25. Kandemir, A. Endemic plants of Erzincan and threatening. In Proceedings of the Biological Diversity Symposium, Ankara, Turkey, 22-23 May 2012; pp. 108-109.

26. Akpinar, E.; Celikoglu, S. The contribution of Cimin (black plum) grape to the economy and publicity of Erzincan. In Proceedings of the International Erzincan Symposium, Erzincan, Turkey, 28 September-1 October 2016; Volume 2, pp. 16-23.

27. Keskin, O. Vine and the worm of grapevine: Struggle against phylloxera in the Ottoman Empire. J. Hist. Investig. 2015, 30, 479-505.

28. Gökbayrak, Z. Bağcılığın Belalı Zararlısı: Filoksera. Alatarım 2006, 5, 37-43.

29. Karadogan, B.; Keskin, N.; Kunter, B.; Oguz, D.; Kalkan, N.N. Comparison of Karaerik (Cimin) clones for total phenolic and antioxidant contents. Bahce 2018, 1, 117-120.

30. Kupe, M.; Karatas, N.; Unal, M.S.; Ercisli, S.; Baron, M.; Sochor, J. Phenolic composition and antioxidant activity of peel, pulp and seed extracts of different clones of the Turkish grape cultivar 'Karaerik'. Plants 2021, 10, 2154. [CrossRef] [PubMed]

31. Bungau, S.; Behl, T.; Aleya, L.; Bourgeade, P.; Aloui-Sosse, B.; Purza, A.L.; Abid, A.; Samual, A.D. Expatiating the impact of anthropogenic aspects and climatic factors on long term soil monitoring and management. Environ. Sci. Pollut. Res. 2021, 202, 30528-30550. [CrossRef]

32. Gitea, M.A.; Gitea, D.; Tit, D.M.; Purza, L.; Samual, A.D.; Bungau, S.; Badea, G.E.; Aleya, L. Orchard management under the effects of climate change: Implications for apple, plum, and almond growing. Environ. Sci. Pollut. Res. 2019, 26, 9908-9915. [CrossRef]

33. Gomes, M.J.; Sousa, A.; Novas, J.; Jordão, R.V.D. Environmental sustainability in viticulture as a balanced scorecard perspective of the wine industry: Evidence for the Portuguese region of Alentejo. Sustainability 2021, 13, 10144. [CrossRef]

34. Zebec, V.; Lisjak, M.; Jović, J.; Kujundžić, T.; Rastija, D.; Lončarić, Z. Vineyard fertilization management for iron deficiency and chlorosis prevention on carbonate soil. Horticulturae 2021, 7, 285. [CrossRef]

35. Droulia, F.; Charalampopoulos, I. Future climate change impacts on European Viticulture: A review on recent scientific advances. Atmosphere 2021, 12, 495. [CrossRef]

36. Gattullo, C.E.; Mezzapesa, G.N.; Stellacci, A.M.; Ferrara, G.; Occhiogrosso, G.; Petrelli, G.; Castellini, M.; Spagnuolo, M. Cover crop for a sustainable viticulture: Effects on soil properties and table grape production. Agronomy 2020, 10, 1334. [CrossRef]

37. Provost, C.; Campbell, A.; Dumont, F. Rootstocks impact yield, fruit composition, nutrient deficiencies, and winter survival of hybrid cultivars in eastern Canada. Horticulturae 2021, 7, 237. [CrossRef]

38. Ferrara, G.; Mazzeo, A. Potential and actual bud fruitfulness: A tool for predicting and managing the yield of table grape varieties. Agronomy 2021, 11, 841. [CrossRef]

39. McGovern, P.E.; Fleming, S.J.; Katz, S.H. The Origins and Ancient History of Wine; McGovern, P.E., Fleming, S.J., Katz, S.H., Eds.; Routledge: London, UK, 1996.

40. Eyduran, S.P.; Akin, M.; Ercisli, S.; Eyduran, E.; Maghradze, D. Sugars, organic acids, and phenolic compounds of ancient grape cultivars (Vitis vinifera L.) from lgdir province of Eastern Turkey. Biol. Res. 2015, 48, 2. [CrossRef]

41. Wales, N.; Madrigal, J.R.; Cappellini, E.; Baez, A.C.; Castruita, J.A.S.; Romero-Navarro, J.A.; Carøe, C.; Ávila-Arcos, M.C.; Peñaloza, F.; Moreno-Mayar, J.V.; et al. The limits and potential of paleogenomic techniques for reconstructing grapevine domestication. J. Archaeol. Sci. 2016, 72, 57-70. [CrossRef]

42. Cakan, H.K.; Salih-Girginer, S. Tatarli Höyük (Ceyhan/Adana) evidence of grape growing in the light of archaeobotanical data. 33rd Archeometry Meet. 2017, 1, 373-384. 
43. Fuller, D.Q.; Stevens, C.J. Between domestication and civilization: The role of agriculture and arboriculture in the emergence of the first urban societies. Veg. Hist. Archaeobot. 2019, 28, 263-282. [CrossRef]

44. Ramos-Madrigal, J.; Runge, A.K.W.; Bouby, L.; Lacombe, T.; Castruita, J.A.S.; Adam-Blondon, A.-F.; Figueiral, I.; Hallavant, C.; Martínez-Zapater, J.M.; Schaal, C.; et al. Palaeogenomic insights into the origins of French grapevine diversity. Nat. Plants 2019, 5, 595-603. [CrossRef]

45. Pagnoux, C.; Bouby, L.; Valamoti, S.M.; Bonhomme, V.; Ivorra, S.; Gkatzogia, E.; Karathanou, A.; Kotsachristou, D.; Kroll, H.; Terral, J.-F. Local domestication or diffusion? Insights into viticulture in Greece from Neolithic to Archaic times, using geometric morphometric analyses of archaeological grape seeds. J. Archaeol. Sci. 2021, 125, 105263. [CrossRef]

46. White, C.E.M.; Naomi, F. The Archaeobotany of grape and wine in Hittite Anatolia. Viticulture and wine in Hittite Anatolia and its ancient near eastern context: Philological, archaeological and comparative perspectives. In Die Welt Des Orients; Vandenhoeck \& Ruprecht (GmbH \& Co. KG): Göttingen, Germany, 2018; pp. 209-224.

47. Gökbayrak, Z.; Söylemezoğlu, G. Grapevine throughout the History of Anatolia. Int. J. Bot. 2010, 6, 1-8. [CrossRef]

48. Deliorman, O.D.; Ergun, F.; Orhan, N. Grape (Vitis vinifera L.) in Anatolian civilizations. Hist. Res. J. 2011, 30, 68-80.

49. Cigdem, S. Livelihoods and lifestyles of ancient Anatolian people. Ph.D. Thesis, Atatürk University Social Sciences Institute, Erzurum, Turkey, 1996.

50. Saglam, C.O.; Saglam, H. The importance of grape in human history. J. Agric. 2018, 1, 1-10.

51. Soylemezoglu, G.; Atak, A.; Boz, Y.; Unal, A.; Saglam, M. Viticulture in Turkey. Chron. Hortic. 2016, 56, $27-31$.

52. Stanislawski, D. Dionysus westward: Early religion and the economic geography of wine. Geogr. Rev. 1975, 65, 427-444. [CrossRef]

53. Harrison, J.E. Mythology; Marshall Jones Company: Boston, MA, USA, 1924; Volume 26.

54. Candar, S.; Uysal, T.; Ayaz, A.; Akdemir, U.; Korkutal, I.; Bahar, E. Viticulture tradition in Turkey. Vitic. Stud. (VIS) 2021, 1, 39-54. [CrossRef]

55. Çizer, O. Archaeobotanical Macro Remains from Late Bronze Age Kinet Höyük and Tell Atchana (Alalakh) in Southern Turkey: Economical and Environmental Considerations. Masters's Thesis, Eberhard-Karls Universität Tübingen, Institut für Ur- und Frühgeschichte und Archäologie des Mittelalters, Abteilung für Ältere Urgeschichte und Quartärökologie, Tübingen, Germany, 2006.

56. Bending, J.; Colledge, S. The Archaeobotanical Assemblages In Excavations at Kilise Tepe, 1994-1998, from Bronze Age to Byzantine in Western Cilicia; Postgate, N., Thomas, D., Eds.; McDonald Institute Monographs: Cambridge, UK, 2007; pp. 583-595, Appendix, I

57. Akgezer, B. Dionysos, Özgürlüğün Şarkısı; Yitik Ülke Yayınları: Istanbul, Turkey, 2018.

58. Şenocak, E. The place of grape in Turkish folk culture and in context of mythology. J. Turk. Stud. 2008, 3, 175-192. [CrossRef]

59. Uhri, A. The long trip of grape in Mediterranean. In Proceedings of the Conference on Long Trip of Grape in Mediterranean, Izmir, Turkey, 16 April 2016.

60. Anl1, E. Grape and Grape Culture; Yapi Kredi Publication: Istanbul, Turkey, 2007; p. 240.

61. Gürkan, H. The Importance of Vine Plant Throughout History and Its Use today. Bachelor's Thesis, Erciyes University Pharmacy Faculty Graduate Thesis, Kayseri, Turkey, 2014; p. 106.

62. Aksit, I. Hittites. In Turkey's Historical Treasures, Central Anatolian Civilization; Sandoz Publications: Istanbul, Turkey, $1981 ;$ p. 160.

63. Mutlu, B. Formation in Western Art and the Eastern Mediterranean; Istanbul Fine Arts Academy Publications: Istanbul, Turkey, 1977; p. 89.

64. Laneri, N.; Schwartz, M.; Ur, J.; d'Agostino, A.; Berthon, R.; Hald, M.M.; Marsh, A. Ritual and Identity in Rural Mesopotamia: Hirbirmedon Tepe and the Upper Tigris River Vally in the Middle Bronze Age. AJA 2015, 119, 533-564. [CrossRef]

65. Celikbas, E.; Verim, E. Bema and Apse Mosaics of the Northwest Necropolis Church of Hadrianoupolis. J. Mosaic Res. 2021, 14, 79-99.

66. Can, B. Erzincan Altıntepe Church with Mosaic. J. Mosaic Res. 2009, 3, 5-13.

67. Yıldırım, F. Wines in Ottomans according to 'Mühimme notebooks'. J. Soc. Sci. Firat Univ. 2021, 31, $495-514$.

68. Miroglu, I. Erzincan city at first period of XVI century (1516-1530). Istanbul Univ. Fac. Lit. J. Hist. 1974, 71-82.

69. Evliya Çelebi Seyahatnâmei, Süleymaniye Kütüphanesi Hacı Beşir Ağa Türkçe Yazmalar Koleksiyonu, nr. 448. Available online: http:/ / www.yazmalar.gov.tr/sayfa/koleksiyonlar/15 (accessed on 5 January 2022).

70. Evliya Çelebi Seyahatnâmesi, C.2, İkdam Matbaası, Dersaadet 1314. Available online: https://kutuphane.ttk.gov.tr/details?id= $542009 \&$ materialType $=$ NE\&query $=$ Evliya $+\%$ C3\%87elebi (accessed on 5 January 2022).

71. Akpinar, E.; Yigit, D. The effect of ecological factors on growth of Karaerik grape cultivar. East Geogr. J. $2006,11,39-62$.

72. Karadogan, B.; Keskin, N. Quality and phytochemical characteristics of Karaerik (Vitis vinifera L. cv. "Karaerik") clones. Turk. J. Agric. Nat. Sci. 2017, 4, 205-212.

73. Kupe, M. Determining Suitable Pruning Level after Winter Frost Damage in Karaerik Grape Cultivar Grown in Uzumlu District of Erzincan. Master's Thesis, Ataturk University Institute of Science, Erzurum, Turkey, 2013; p. 75.

74. Oprea, O.B. Researches on the chemical composition and the rheological properties of wheat and grape epicarp flour mixes. Rev. Chim. 2018, 69, 70-75. [CrossRef]

75. Akter, R.; Rahman, M.H.; Kaushik, D.; Mittal, V.; Uivarosan, D.; Nechifor, A.C.; Behl, T.; Karthika, C.; Stoicescu, M.; Munteanu, M.A.; et al. Chemo-preventive action of resveratrol: Suppression of p53-A molecular targeting approach. Molecules 2021, $26,5325$. [CrossRef] [PubMed] 
76. Behl, T.; Bungau, S.; Kumar, K.; Zengin, G.; Khan, F.; Kumar, A.; Kaur, R.; Venkatachalam, T.; Tit, D.M.; Vesa, C.M.; et al. Pleotropic effects of polyphenols in cardiovascular system. Biomed. Pharm. 2020, 130, 110714. [CrossRef]

77. Dopico-García, M.S.; Fique, A.; Guerra, L.; Afonso, J.M.; Pereira, O.; Valentão, P.; Andrade, P.B.; Seabra, R.M. Principal components of phenolics to characterize red Vinho Verde grapes: Anthocyanins or non-coloured compounds. Talanta 2008, 75, 1190-1202. [CrossRef]

78. AlBasher, G.; Abdel-Daim, M.M.; Almeer, R.; Ibrahim, K.A.; Hamza, R.Z.; Bungau, S.; Aleya, L. Synergistic antioxidant effects of resveratrol and curcumin against fipronil-triggered oxidative damage in male albino rats. Environ. Sci Pollut. Res. 2020, 27, 6505-6514. [CrossRef]

79. Dzhambazova, T.; Kondakova, V.; Tsvetkov, I.; Batchvarova, R. Grape Secondary Metabolites. Benefits for Human Health. In Advance Understanding of Neurodegerenati ve Disease; Intech Open: London, UK, 2011; pp. 285-296.

80. Lim, T.K. Edible Medicinal and Non-Medicinal Plants. Volume 6, Fruits. Vitaceae; Springer Science and Business Media: Dordrecht, The Netherlands, 2013; pp. 450-482.

81. Manach, C.; Scalbert, A.; Morand, C.; Remsy, C.; Jimenez, L. Polyphenols: Food sources and bioavailability. Am. J. Clin. Nutr. 2004, 79, 727-747. [CrossRef]

82. Lee, H.; Kim, K.; Lee, O.; Lee, B. Effect of pycnogenol®on glucose transport in mature 3T3-L1 adipocytes. Phytother. Res. 2010, 24 1242-1249. [CrossRef]

83. Morand, C.; Dubray, C.; Milenkovic, D.; Lioger, D.; Martin, J.; Scalbert, A.; Mazur, A. Hesperidin contributes to the vascular protective effects of orange juice: A randomized crossover study in healthy volunteers. Am. J. Clin. Nutr. 2010, 93, 73-80. [CrossRef] [PubMed]

84. Mikhailidis, D.P.; Elisaf, M.; Rizzo, M.; Berneis, K.; Griffin, B.; Zambon, A.; Athyros, A.; de Graaf, J.; März, W.; Parhofer, K.G. European panel on low density lipoprotein (LDL) subclasses": A statement on the pathophysiology, atherogenicity and clinical significance of LDL subclasses. Curr. Vasc. Pharmacol. 2011, 9, 533-571. [CrossRef] [PubMed]

85. Belcaro, G.; Dugall, M.; Hosoi, M.; Ippolito, E.; Cesarone, M.; Luzzi, R.; Cornelli, U.; Ledda, A. Pycnogenol ${ }^{\circledR}$ and Centella asiatica for asymptomatic atherosclerosis progression. Int. Angiol. 2014, 33, 20-26. [PubMed]

86. Toth, P.; Patti, A.; Nikolic, D.; Giglio, R.; Castellino, G.; Biancucci, T.; Geraci, F.; David, S.; Montalto, G.; Rizvi, A. Bergamot reduces plasma lipids, atherogenic small dense LDL and subclinical atherosclerosis in subjects with moderate hypercholesterolemia: A 6 months prospective study. Front. Pharmacol. 2016, 6, 299. [CrossRef] [PubMed]

87. Naruszewicz, M.; Łaniewska, I.; Millo, B.; Dłuzniewski, M. Combination therapy of statin with flavonoids rich extract from chokeberry fruits enhanced reduction in cardiovascular risk markers in patients after myocardial infraction (MI). Atherosclerosis 2007, 194, e179-e184. [CrossRef] [PubMed]

88. Dohadwala, M.; Holbrook, M.; Hamburg, N.; Shenouda, S.; Chung, W.; Titas, M.; Kluge, M.; Wang, N.; Palmisano, J.; Milbury, P.E. Effects of cranberry juice consumption on vascular function in patients with coronary artery disease. Am. J. Clin. Nutr. 2011, 93, 934-940. [CrossRef]

89. Xu, T.; Simon, J.E.; Ferruzzi, M.G.; Ho, L.; Pasinetti, G.M.; Wu, Q. Quantification of anthocyanidins in the grapes and grape juice products with acid assisted hydrolysis using LC/MS. J. Funct. Foods 2012, 4, 710-717. [CrossRef]

90. Alvarez-Suarez, J.; Giampieri, F.; Tulipani, S.; Casoli, T.; Di Stefano, G.; Gonzalez Paramas, A.; Santos-Buelga, C.; Busco, F.; Quiles, J.L.; Cordero, M.D. One-month strawberry-rich anthocyanin supplementation ameliorates cardiovascular risk, oxidative stress markers and platelet activation in humans. J. Nutr. Biochem. 2014, 25, 289-294. [CrossRef]

91. Santhakumar, A.; Kundur, A.; Fanning, K.; Netzel, M.; Stanley, R.; Singh, I. Consumption of anthocyanin-rich Queen Garnet plum juice reduces platelet activation related thrombogenesis in healthy volunteers. J. Funct. Foods. 2015, 12, 11-22. [CrossRef]

92. Cassidy, A.; Bertoia, M.; Chiuve, S.; Flint, A.; Forman, J.; Rimm, E. Habitual intake of anthocyanins and flavanones and risk of cardiovascular disease in men. Am. J. Clin. Nutr. 2016, 104, 587-594. [CrossRef]

93. Krízova, L.; Dadakov, K.; Kasparovska, J.; Kasparovský, T. Isoflavones. Molecules 2019, 24, 1076. [CrossRef] [PubMed]

94. Zamora-Ros, R.; Andres-Lacueva, C.; Lamuela-Raventos, R.; Berenguer, T.; Jakszyn, P.; Martínez, C.; Sánchez, M.J.; Navarro, C.; Chirlaque, M.D.; Tormo, M.-J. Concentrations of resveratrol and derivatives in foods and estimation of dietary intake in a Spanish population: European Prospective Investigation into Cancer and Nutrition (EPIC)-Spain cohort. Br. J. Nutr. 2008, 100, 188-196. [CrossRef] [PubMed]

95. Wong, R.; Howe, P.; Buckley, J.; Coates, A.; Kunz, I.; Berry, N. Acute resveratrol supplementation improves flow-mediated dilatation in overweight/obese individuals with mildly elevated blood pressure. Nutr. Metabol. Cardiovasc. Dis. 2011, 21, 851-856. [CrossRef] [PubMed]

96. Tome-Carneiro, J.; Gonzalvez, M.; Larrosa, M.; Yanez-Gascon, M.; García Almagro, F.; Ruiz-Ros, J.; García-Conesa, M.T.; TomásBarberán, F.A.; Espín, J.C. One-year consumption of a grape nutraceutical containing resveratrol improves the inflammatory and fibrinolytic status of patients in primary prevention of cardiovascular disease. Am. J. Cardiol. 2012, 110, 356-363. [CrossRef]

97. Tome-Carneiro, J.; Gonzalvez, M.; Larrosa, M.; Yanez-Gascon, M.; García Almagro, F.; Ruiz-Ros, J.; García-Conesa, M.T.; TomásBarberán, F.A.; Espín, J.C. Grape resveratrol increases serum adiponectin and downregulates inflammatory genes in peripheral blood mononuclear cells: A triple-blind, placebo-controlled, one-year clinical trial in patients with stable coronary artery disease. Cardiovasc. Drugs. Ther. 2012, 27, 37-48. [CrossRef] 
98. Militaru, C.; Donoiu, I.; Craciun, A.; Scorei, I.; Bulearca, A.; Scorei, R. Oral resveratrol and calcium fructoborate supplementation in subjects with stable angina pectoris: Effects on lipid profiles, inflammation markers, and quality of life. Nutrition 2013, 29, 178-183. [CrossRef]

99. Calabriso, N.; Massaro, M.; Scoditti, E.; Pellegrino, M.; Ingrosso, I.; Giovinazzo, G.; Carluccio, M.A. Red grape skin polyphenols blunt matrix metalloproteinase- 2 and -9 activity and expression in cell models of vascular inflammation: Protective role in degenerative and inflammatory diseases. Molecules 2016, 21, 1147. [CrossRef]

100. Massaro, M.; Scoditti, E.; Calabriso, N.; Carluccio, M.; Hugenholtz, P.; De Caterina, R. Nutrients and Gene Expression in Cardiovascular Disease. In Principles of Nutrigenetics and Nutrigenomics; Erasmus MC: Rotterdam, The Netherlands, 2020; pp. 469-481. [CrossRef] 